\title{
Inheritance of resistance to root-lesion nematode (Pratylenchus thornei) in wheat landraces and cultivars from the West Asia and North Africa (WANA) region
}

\author{
J. P. Thompson ${ }^{\mathrm{A}, \mathrm{B}}$ and N. P. Seymour ${ }^{\mathrm{A}}$ \\ ${ }^{A}$ Agri-Science Queensland, Department of Employment, Economic Development and Innovation, \\ Leslie Research Centre, PO Box 2282, Toowoomba, Qld 4350, Australia. \\ ${ }^{\mathrm{B}}$ Corresponding author. Email: john.thompson@deedi.qld.gov.au
}

\begin{abstract}
The root-lesion nematode Pratylenchus thornei causes substantial loss to bread wheat production in the northern grain region of Australia and other parts of the world. West Asia and North Africa (WANA) wheat accessions with partial resistance to $P$. thornei were analysed for mode of inheritance in a half-diallel crossing design of $F_{1}$ hybrids (10 parents) and $\mathrm{F}_{2}$ populations (7 parents). General combining ability was more important than specific combining ability as indicated by components of variance ratios of 0.93 and 0.95 in diallel ANOVA of the $\mathrm{F}_{1}$ and $\mathrm{F}_{2}$ generations, respectively. General combining ability values of the 'resistant' parents were predictive of the mean nematode numbers of their progeny in crosses with the susceptible Australian cv. Janz at the $\mathrm{F}_{1}\left(R^{2}=0.86, P<0.001,8\right.$ crosses $), \mathrm{F}_{2}\left(R^{2}=0.83\right.$, $P<0.001,9$ populations) and $\mathrm{F}_{\infty}\left(R^{2}=0.71, P<0.05,5\right.$ doubled-haploid populations $)$. The $\mathrm{F}_{2}$ and $\mathrm{F}_{\infty}$ populations showed relatively continuous distributions. Heritability was 0.68 for $F_{2}$ populations in the half-diallel of resistant parents and 0.82-0.92 for 5 'resistant' parent/Janz doubled-haploid populations (narrow-sense heritability on a line mean basis). The results indicate polygenic inheritance of $P$. thornei resistance with a minimum of from 2 to 6 genes involved in individual $\mathrm{F}_{\infty}$ populations of 5 resistant parents crossed with Janz. Morocco 426 and Iraq 43 appear to be the best of the parents tested for breeding for resistance to $P$. thornei. None of the $P$. thornei-resistant WANA accessions was resistant to Pratylenchus neglectus.
\end{abstract}

Additional keywords: Pratylenchus neglectus, transgressive segregants.

\section{Introduction}

Wheat is cultivated worldwide with an annual production of $\sim 780 \mathrm{M}$ tonnes, which is third after maize and rice of all cereals. Because of wheat's higher protein content it is the most important source of vegetable protein for human nutrition. Spring wheat (Triticum aestivum) is the major cereal grown in winter in the subtropical, subhumid, northern grain region of Australia (Webb et al. 1997) with average annual production of 3.7 $\mathrm{M}$ tonnes from 2.24 M hectares (Murray and Brennan 2009). Hard white wheat of high protein content that is favoured for bread and ramen noodles is produced. Root-lesion nematodes (Pratylenchus thornei and $P$. neglectus) are a significant problem for wheat production in the northern region (Thompson et al. 2008), other regions of Australia (Vanstone et al. 2008) and other countries (Nicol et al. 2003; Smiley and Nicol 2009). P. thornei occurs more frequently and at higher population densities than $P$. neglectus in the Australian northern grain region (Thompson et al. 2010). Present economic loss from $P$. thornei in the northern grain region has been estimated at AUD $\$ 38 \mathrm{M} /$ year based on a 10 -year average wheat price of AUD\$239/tonne, whereas the potential economic loss without existing management of the problem would be AUD\$104 M/year (Murray and Brennan 2009).

Root-lesion nematodes feed, reproduce and migrate in the root cortex of wheat resulting in lesions and debilitated root systems that are inefficient at extracting nutrients and water from the soil. Evidence of the belowground pathogenic activity of the nematodes can be seen as aboveground symptoms of chlorosis and wilting of leaves, and reduced tillering, biomass and grain yield. Key components of effective integrated management of $P$. thornei in the northern grain region are crop rotation and the use of tolerant and resistant crop cultivars (Thompson et al. 2008). Tolerant cultivars suffer little yield reduction even though their roots are invaded by nematodes, whereas resistant cultivars retard the rate of nematode multiplication in the roots (Roberts 2002). Resistant cultivars leave fewer nematodes in the soil to attack subsequent crops thereby contributing to productivity of the whole farming system, and growing cultivars that have greater resistance than current cultivars would also diminish chances for continued spread of $P$. thornei to uninfested fields in the northern grain region (Thompson et al. 2010). For polycyclic nematode species like $P$. thornei, resistance can also reduce yield loss in the current crop by delaying the build up of nematodes during the growing season and thereby reducing plant damage (Trudgill 1991; Thompson et al. 2000).

Although progress has been made with breeding some tolerant bread wheat cultivars for the northern grain region of Australia such as Baxter, EGA Gregory, EGA Wylie and Sunvale, most 
cultivars are susceptible allowing the nematodes to multiply to high populations (DPIF 2009; Thompson et al. 1999, 2008). One bread wheat source of partial resistance is GS50a, which was selected from within the Australian wheat cv. Gatcher, which itself is susceptible and intolerant (Thompson et al. 1999). To find other sources of resistance to $P$. thornei, research was conducted on accessions from the West Asia and North Africa (WANA) region (Thompson et al. 2009) in the Watkins Collection of wheat landraces (Miller et al. 2001) and the McIntosh Collection of cultivars (described by Thompson et al. 2009). Thirteen bread wheat accessions that produced nematode numbers similar to the partially resistant GS50a were identified. These new sources of resistance offer possibilities for breeding wheat cultivars that have a high level of durable resistance to $P$. thornei. One challenge is choosing which among these partially resistant wheat accessions would produce the best genetic gains when used as resistant parents in a breeding program.

This paper describes research on some of the more resistant of the WANA wheat accessions identified by Thompson et al. (2009) that aimed to (i) determine whether the resistances to $P$. thornei are genetically different from each other, (ii) determine whether combining resistance genes from more than one source will provide greater levels of resistance, (iii) determine the most efficient breeding strategies for genetic gain in resistance to $P$. thornei, and (iv) introduce the most resistant gene combinations into an adapted bread wheat background for use in wheat breeding programs. To achieve these ends, a half-diallel of crosses was made between 9 of the resistant WANA wheat accessions and GS50a. In a half-diallel mating design each parent is crossed once with every other parent without reciprocal crosses (Falconer and Mackay 1996). Reciprocal crossing is required only if cytoplasmic inheritance might influence the trait of interest, which is considered to be rare in plant breeding (Falconer and Mackay 1996). Resistance to P. thornei of progeny from this half-diallel was investigated at the $\mathrm{F}_{1}$ and $\mathrm{F}_{2}$ generations and diallel ANOVA and other analyses conducted to determine the relative values of these sources of resistance as parents in crosses. From these data, combining abilities of the parents (Griffing 1956) were determined. General combining ability (GCA) is the average performance (in this instance for $P$. thornei resistance) of a parent in hybrid combinations, whereas specific combining ability (SCA) refers to crosses where hybrid performance is relatively better or worse than expected from the sum of the GCA of the two parents (Sprague and Tatum 1942; Christie and Shattuck 1992). In addition, crosses between the 'resistant' parents and the susceptible Australian wheat cv. Janz were investigated for resistance to $P$. thornei at the $\mathrm{F}_{1}, \mathrm{~F}_{2}$ and $\mathrm{F}_{\infty}$ (doubled-haploid, DH) generations. The 10 parental sources of resistance to $P$. thornei were also tested for resistance to $P$. neglectus in order to find accessions with resistance to both nematode species.

\section{Materials and methods}

\section{Wheat accessions}

Seven of the most $P$. thornei-resistant bread wheat accessions from the study described by Thompson et al. (2009) were selected for this investigation, namely, 5 from the Watkins Collection [Iraq 43 (AUS 4926), Morocco 426 (AUS 13124), Persia 11
(AUS 5197), Persia 28 (AUS 5216) and Persia 62 (AUS 5221)], and 2 from the McIntosh Collection [El Neilain (ISR 455.3) from Sudan and C-70-3 (ISR 484.14) from Iran]. Two other WANA wheats were included that were not among the most resistant in the study of Thompson et al. (2009). These were Persia 92 (AUS 5258), which showed excellent tolerance to $P$. thornei in field tests conducted as described by Thompson et al. (1999), and Iraq 48 (AUS 4930), which had previously been found to be resistant to cereal cyst nematode (CCN, Heterodera avenae) (the late F. Green, pers. comm. 1995) and to P. thornei (Nicol 1996). Also included were GS50a (the partially resistant selection from Gatcher), and Janz a widely adapted Australian cultivar susceptible to $P$. thornei.

\section{Half-diallel and progeny generations}

A half-diallel mating design of pair-wise crosses between the 10 'resistant' accessions was made in the crossing plots at the Leslie Research Centre, Toowoomba, Australia $\left(27.55^{\circ} \mathrm{S}, 151.95^{\circ} \mathrm{E}\right)$, in 1997. Out of the 45 crosses in the half-diallel, seed was not available for 2, namely C-70-3/GS50a and El Neilain/Iraq 48. In addition, crosses were made between Janz and the 10 'resistant' parents. The $F_{1}$ seed from the half-diallel of 'resistant' parents and the $F_{1}$ seed from the crosses of the 'resistant' parents with Janz were used in Expts 1 and 2, respectively, as described below. $\mathrm{F}_{2}$ seed that was harvested from Expts 1 and 2 was used in Expts 3 and 4, respectively. DH lines from $\mathrm{F}_{1}$ seed of crosses of selected 'resistant' accessions with Janz were produced by Dr N. Howes at the South Australian Research and Development Institute using procedures similar to that described by Thomas et al. (1997) with colchicine treatment for chromosome doubling (N. Howes, pers. comm. 1999). Plants from this DH seed were tested for resistance to P. thornei in Expt 5. P. thornei-'resistant' parents used in the half-diallel were tested for resistance to $P$. neglectus in Expt 6.

Experiment 1. Resistance to $\mathrm{P}$. thornei of $F_{1}$ hybrids from a half-diallel design of crosses of 10 'resistant' wheat accessions

An experiment was designed to test the resistance to $P$. thornei of $\mathrm{F}_{1}$ plants from all crosses except those involving Janz, i.e. $43 \mathrm{~F}_{1}$ hybrids, as well as the 10 parental lines, using methods similar to those described by Thompson and Haak (1997) and Thompson et al. (2009). Nine other treatments included in the experiment as reference standards were an unplanted control, canaryseed (Phalaris canariensis cv. Morocco), the partially resistant durum wheat cv. Yallaroi, the susceptible bread wheat cvv. Cunningham, Janz, Gatcher and Batavia, and the partially resistant fixed lines QT9048 and QT8343 derived from previous crossing of GS50a with cvv. Janz and Cunningham.

Single plants were grown in pots $(15 \mathrm{~cm}$ diameter $\times 15 \mathrm{~cm}$ high) containing $1 \mathrm{~kg}$ vertosolic soil of the Irving Series (Thompson and Beckmann 1959) previously pasteurised by aerated steam at $70^{\circ} \mathrm{C}$ for $30 \mathrm{~min}$. The soil for each pot was fertilised with nutrients in solution to provide $200 \mathrm{mg} \mathrm{NO}-\mathrm{N}$, $25 \mathrm{mg} \mathrm{P}, 88 \mathrm{mg} \mathrm{K}, 36 \mathrm{mg} \mathrm{S}, 285 \mathrm{mg} \mathrm{Ca}$ and $5 \mathrm{mg} \mathrm{Zn/kg} \mathrm{soil} \mathrm{and}$ inoculated with $2500 P$. thornei $/ \mathrm{kg}$ soil, which had been raised as pure cultures on wheat. All treatments were replicated 6 times and the pots were laid out in a randomised complete block design in a glasshouse at the Leslie Research Centre, Toowoomba. The 
plants were grown from June to October on benches with underbench heating to maintain the soil temperature at $22^{\circ} \mathrm{C}$. Soil moisture content was initially brought to $\mathrm{pF} 2\left(0.56 \mathrm{~g} \mathrm{~g}^{-1}\right.$ gravimetric) and readjusted as required during plant growth. At 16 weeks after sowing, the intact plant was removed from the pot and one vertical half of the soil and roots was excised and stored in a sealed plastic bag in a cold room at $3^{\circ} \mathrm{C}$ pending nematode enumeration. Fresh soil was added to the pot and the plant was grown on for seed harvest. The excised soil containing roots was manually broken into pieces $<5 \mathrm{~mm}$. Nematodes were extracted from 150-g subsamples by the Whitehead tray method (Whitehead and Hemming 1965) during $48 \mathrm{~h}$ at $22^{\circ} \mathrm{C}$, and counted in a Hawksley slide under a compound microscope.

Nematode populations were expressed as number/kg ovendry soil equivalent. These data were transformed by $\ln (x+c)$ (Proctor and Marks 1974) with the c-value optimised using a Chisquare test in GENSTAT (Payne et al. 2008) to minimise residuals (Berry 1987) in an ANOVA. Values for missing crosses were estimated by the method of Eckhardt (1952). DIALLEL analysis and simulation software (Burow and Coors 1994) was used to analyse the transformed data by Griffing's (1956) Method 4 (no parents or reciprocals) with Model 1 (fixed effects), to determine variances and effects of GCA and SCA of the resistant parents in terms of nematode numbers. The components of variance ratio (Baker 1978; Navabi et al. 2004) was calculated as:

$$
2 \sigma_{\mathrm{GCA}}^{2} /\left(2 \sigma_{\mathrm{GCA}}^{2}+\sigma_{\mathrm{SCA}}^{2}\right)
$$

where $\sigma_{\text {GCA }}^{2}=$ GCA mean square and $\sigma_{\text {SCA }}^{2}=$ SCA mean square from the half-diallel ANOVA. Baker (1978) stated that the closer the resultant value is to unity the greater the predictability of hybrid performance based on GCA alone.

Experiment 2. Resistance to $\mathrm{P}$. thornei of $F_{1}$ hybrids from crosses between 10 'resistant' wheat accessions and the susceptible Australian wheat cv. Janz

The $10 \mathrm{~F}_{1}$ hybrids from Janz crossed with the respective 'resistant' parents as well as the parents themselves and reference standards (as for Expt 1) were tested for $P$. thornei resistance in 6 replications. Single plants were grown in $330 \mathrm{~g}$ (oven-dry equivalent) of pasteurised soil in $70-\mathrm{mm}^{2}$ pots (150 mm high) designed for bottom watering and inoculated with 3300 P. thornei per pot. Plants were grown with nutrients as for Expt 1. Soil temperature was maintained at $22^{\circ} \mathrm{C}$ by underbench heating and water tension at $2 \mathrm{~cm}$ by capillary matting and a float valve. At 16 weeks after sowing, the soil (including roots) from the bottom one-third of each pot was excised and processed for nematode enumeration as described in Expt 1. Soil was replaced in the pots and the plants were grown on for seed collection. Nematodes were extracted and counted as described for Expt 1.

Experiment 3. Resistance to $\mathrm{P}$. thornei of $F_{2}$ populations from a half-diallel design of crosses of 7 'resistant' wheat accessions

From the analysis of $\mathrm{F}_{1}$ data, parents were ranked in order of GCA effects. Crosses involving the 6 parents with greatest GCA effects for resistance, namely, Iraq 43, Morocco 426, Persia 11, Persia 62, GS50a and C-70-3, as well as Iraq 48 (because of its previous use as a resistant parent in breeding programs (Nicol 1996; P. S. Brennan, pers. comm. 1997), were selected for an $F_{2}$ experiment. One-hundred $\mathrm{F}_{2}$ seeds of each of the selected crosses ( 17 seeds from each of 5 replicate $F_{1}$ plants in Expt 1 and 15 from the 6 th replicate) along with 6 replicates of parents and reference standards were tested for resistance to $P$. thornei using methods similar to those for Expt 2. Diallel analysis (Burow and Coors 1994) was conducted as described for Expt 1 using data for individual $\mathrm{F}_{2}$ (first 87 plants in each cross; because of plant death, data were available for 87-97 plants in individual crosses) without blocking. A second diallel analysis was conducted using all plant data for each cross entered as 6 mean values based on the source of the $\mathrm{F}_{2}$ seed from the $6 \mathrm{~F}_{1}$ plants; these results were similar to those obtained from analysis based on the 87 individuals and will not be presented here.

Numbers of $P$. thornei produced in the roots of individual $\mathrm{F}_{2}$ progeny of each cross were examined graphically and statistically [using $\ln (x+500)$ transformations] in relation to their parents to learn whether transgressive segregation towards greater resistance and/or greater susceptibility occurred within the $\mathrm{F}_{2}$ population. Estimates of residual error variance for each cross were available from replicated reference standards; however, these were excluded from the estimates of genetic variance for each population. The variance-covariance matrix of the predicted (transformed) numbers of $P$. thornei for parents and $\mathrm{F}_{2}$ progeny from a random effects analysis was used to assess transgressive segregation. An individual $\mathrm{F}_{2}$ was deemed to be a resistant (or a susceptible) transgressive segregant if it had a transformed count with a probability of at least 0.95 of being lower (or higher) than the resistant (or susceptible) parent.

Experiment 4. Resistance to $\mathrm{P}$. thornei of $F_{2}$ from crosses between each 'resistant' wheat and the susceptible Australian wheat CV. Janz

One-hundred and ten $\mathrm{F}_{2}$ seeds from each of the 10 families from the 10 'resistant' wheat accessions crossed with Janz, along with 6 replicates of parents and reference standards, were tested for P. thornei resistance by methods as described for Expt 2.

Experiment 5. Resistance to $\mathrm{P}$. thornei of $\mathrm{DH}$ populations from crosses between 5 'resistant' wheat accessions and Janz

The DH seed produced from $\mathrm{F}_{1}$ plants of crosses between the susceptible wheat Janz and each of 5 of the 'resistant' wheats, namely, Iraq 43, Morocco 426, GS50a, Persia 11 and El Neilain [which had been selected for this purpose as the most resistant bread wheats in the first experiment on WANA wheats described by Thompson et al. (2010)], were assessed for resistance to $P$. thornei. From each population, $126 \mathrm{DH}$ lines were tested in 6 replications along with parents and reference standards as listed in Expt 1. The pots were laid out in spatial designs on glasshouse benches and all other procedures were as described under Expt 2 above.

Initial ANOVA was conducted on data for number of $P$. thornei by treating $\mathrm{DH}$ lines in each population, parents and standards as fixed effects. Subsequently, transformed numbers of $P$. thornei for the $\mathrm{DH}$ lines were analysed as random effects in order to estimate variance components using ASReml (Gilmour et al. 2002). Variance components were used to estimate 
narrow-sense heritability from the ANOVA of each $\mathrm{DH}$ population on a line-mean basis using the following formula (Fehr 1987):

$$
\begin{gathered}
h^{2}=\sigma_{\mathrm{g}}^{2} /\left(\sigma_{\mathrm{g}}^{2}+\sigma_{\mathrm{e}}^{2} / r\right) \\
\sigma_{\mathrm{g}}^{2}=\left(\sigma_{\mathrm{dhl}}^{2}-\sigma_{\mathrm{e}}^{2}\right)
\end{gathered}
$$

where $h^{2}=$ heritability estimate, $\sigma_{\mathrm{g}}^{2}=$ genetic variance, $\sigma_{\mathrm{dhl}}^{2}=$ variance of the DH lines, $\sigma_{\mathrm{e}}^{2}=$ error variance, and $r=$ number of replicates.

Since $\mathrm{DH}$ are genetically fixed homozygotes at $\mathrm{F}_{\infty}$ there is no dominance effect and therefore $h^{2}$ is an estimate of narrow-sense heritability (additive effects).

The minimum number of genes controlling resistance to $P$. thornei in each $\mathrm{DH}$ population was calculated using Wright's (1968) method as modified by Cockerham (1983) for the level of inbreeding and as applied by Singh et al. (1995) to $F_{6}$ populations and by Herrera-Foessel et al. (2008) to $\mathrm{F}_{5}$ populations. The modified formula applicable to $\mathrm{DH}$ is $n=(\mathrm{GR})^{2} / 4 \sigma_{\mathrm{g}}^{2}$ in which $n=$ minimum number of effective genes, $\mathrm{GR}=$ genotypic range, and $\sigma_{\mathrm{g}}^{2}=$ genetic variance of the DH lines (Herrera-Foessel et al. 2008; S. A. Herrera-Foessel, pers. comm. 2010). GR was determined by multiplying the phenotypic range of the DH mean values by the heritability $\left(h^{2}\right)$.

Experiment 6. Resistance to $\mathrm{P}$. neglectus of $\mathrm{P}$. thornei'resistant' parents

All of the parents used in the half-diallel for resistance to $P$. thornei were assessed for resistance to $P$. neglectus. In addition to the reference standards listed in Expt 1, the following accessions were included in the experiment: Persia 20 (AUS 5205) and Virest (AUS 11984) both considered to be resistant to $P$. neglectus (Das et al. 2004), Abacus a resistant triticale (Farsi et al. 1995), and various South Australian wheat cultivars with different reactions to $P$. neglectus, namely, partially resistant Krichauff, Excalibur and Worrakata, and susceptible Machete and Spear (Vanstone et al. 1998). The experiment was conducted as described for Expt 2 but inoculated with 3300 $P$. neglectus/pot of $330 \mathrm{~g}$ soil instead of with $P$. thornei.

\section{Results}

Experiments 1 and 3. Resistance to $\mathrm{P}$. thornei of $F_{1}$ hybrids and $F_{2}$ populations from a half-diallel of crosses of 'resistant' parents

Diallel ANOVA for a number of $P$. thornei in $\mathrm{F}_{1}$ hybrids (Expt 1 ) and $\mathrm{F}_{2}$ populations (Expt 3 ) showed highly significant variation for both GCA and SCA (Table 1). Baker's (1978) ratio of components of variance was 0.93 and 0.95 for the $F_{1}$ and $F_{2}$ analyses, respectively, indicating the greater relative importance of GCA over SCA.

Values of GCA effects for parents based on both $F_{1}$ and $F_{2}$ analyses are given in Table 2 , together with the nematode counts for the parents and reference standards. The number of $P$. thornei after growth of the parents and standards (Table 2) ranged from 280530 and $285290 / \mathrm{kg}$ soil for the susceptible Australian cv. Batavia down to 1390 and $770 / \mathrm{kg}$ soil for the resistant crop canaryseed in Expts 1 and 3, respectively. Among the parents, C-70-3 (3780/kg soil) and Iraq $43(2940 / \mathrm{kg}$ soil) produced the lowest number of $P$. thornei in Expts 1 and 3, respectively, while
Table 1. Diallel ANOVA for combining ability of resistance to Pratylenchus thornei in $F_{1}$ hybrids (Expt 1) and $F_{2}$ populations (Expt 2) from a half-diallel of crosses of 'resistant' parents

Analysis based on $\ln (P$. thornei $/ \mathrm{kg}$ soil +2300$)$ for $\mathrm{F}_{1}$ hybrids and $\ln (P$. thornei $/ \mathrm{kg}$ soil +500$)$ for $\mathrm{F}_{2}$ populations. ${ }^{*} P<0.05 ; * * * P<0.001$; n.s., not significant

\begin{tabular}{lrcrcc}
\hline Source & \multicolumn{2}{c}{$\mathrm{F}_{1}$ hybrids } & \multicolumn{2}{c}{$\mathrm{F}_{2}$ populations } \\
& d.f. & Mean squares & d.f. & Mean squares \\
\hline Replicates & 5 & 1.78 n.s. & - & - \\
Crosses & 44 & $3.19^{* * *}$ & 20 & $26.22^{* * *}$ \\
GCA $^{\mathrm{A}}$ & 9 & $10.06^{* * *}$ & 6 & $70.10^{* * *}$ \\
SCA $^{\mathrm{B}}$ & 33 & $1.43^{*}$ & 14 & $7.42^{* * *}$ \\
Error & 220 & 0.36 & 1806 & 1.4 \\
\hline
\end{tabular}

${ }^{\mathrm{A}} \mathrm{GCA}=$ general combining ability.

${ }^{\mathrm{B}} \mathrm{SCA}=$ specific combining ability.

Iraq 48 (64 140 and $47890 / \mathrm{kg}$ soil) produced the greatest number of $P$. thornei in both experiments. The parents with the greatest GCA effects for resistance (largest negative values) were Iraq 43, Morocco 426 and Persia 11 (Table 2). The parents with the greatest GCA effects towards susceptibility (largest positive values) were Persia 92, Iraq 48, Persia 28 and El Neilain. The parents GS50a, C-70-3 and Persia 62 occupied a middle position in GCA effects.

In Fig. 1, the mean nematode counts (observed values) of the $\mathrm{F}_{1}$ hybrids (Fig. 1a) and $\mathrm{F}_{2}$ populations (Fig. 1b) are shown plotted against the expected values calculated from the GCA values of the respective parents and the grand mean. The difference between the observed and expected values (that is the vertical distance of the observed nematode count from the $1: 1$ diagonal) is the SCA of the particular cross together with the error associated with determining the nematode numbers. Figure 1 clearly shows the generally strong GCA effects on the nematode counts and names all crosses in which there was significant modification by SCA effects. These SCA effects were towards resistance in the $\mathrm{F}_{1}$ hybrids Iraq 43/Iraq 48 and Persia 11/C-70-3 with nematode counts lower than expected from GCA effects alone (Fig. 1a), and towards susceptibility in Persia 92/E1 Neilain, Persia 92/C-70-3, Persia 11/Iraq 48, and Persia 28/Morocco 426 with nematode counts higher than expected from GCA alone (Fig. $1 a$ ). In the $\mathrm{F}_{2}$ populations (Fig. 1b), significant SCA effects towards resistance were shown by GS50a/Iraq 48, Morocco 426/ Iraq 48 and Persia 62/Persia 11 and towards susceptibility by Persia 62/Iraq 48, Persia 11/Iraq 48 and Morocco 426/Iraq 43. Out of the crosses that were tested as both $\mathrm{F}_{1}$ and $\mathrm{F}_{2}$ generations, only Persia 11/Iraq 48 showed consistently significant SCA effects (towards susceptibility).

There were highly significant relationships between the means of the $20 \mathrm{~F}_{2}$ populations regressed against either the mid-parent value (Fig. $2 a$ ) or the sum of the GCA effects of the respective two parents based on diallel analysis of $\mathrm{F}_{1}$ data (Fig. $2 b$ ). The slope of the regression equation of progeny means against mid-parent values provides an estimate of heritability $h^{2}$ (Falconer and Mackay 1996). Based on these $F_{2}$ populations, $h^{2}=0.68$ (Fig. 2a) for $P$. thornei resistance.

Transformed means of $P$. thornei numbers for $\mathrm{F}_{1}$ hybrids and $\mathrm{F}_{2}$ populations were compared with respective mid-parent values (data available as Accessory Publication on journal's website, 
Table 2. Number of Pratylenchus thornei/kg soil after 16 weeks' growth of 'resistant' parents and reference standards with estimates of general combining ability (GCA) effects from a half-diallel of crosses at the $F_{1}$ (Expt 1 ) and $F_{2}$ (Expt 3 ) generations

Parents are ordered on GCA values from $F_{1}$ diallel analysis. Larger negative values of GCA effects indicate better combining ability for resistance. ${ }^{*} P<0.05 ; * * P<0.01 ; * * P<0.001$

\begin{tabular}{|c|c|c|c|c|c|c|}
\hline \multirow[t]{2}{*}{ Genotype } & \multicolumn{2}{|c|}{$\begin{array}{c}\mathrm{F}_{1}(\text { Expt } 1) \\
\text { P. thornei } \mathrm{kg} \text { soil }\end{array}$} & \multicolumn{2}{|c|}{$\begin{array}{l}\mathrm{F}_{2}(\text { Expt } 3) \\
\text { P. thornei } \mathrm{kg} \text { soil }\end{array}$} & \multirow{2}{*}{$\begin{array}{c}\text { Expt } 1 \\
\text { GCA } \\
\left(F_{1}\right)\end{array}$} & \multirow{2}{*}{$\begin{array}{c}\text { Expt } 3 \\
\text { GCA } \\
\left(\mathrm{F}_{2}\right)\end{array}$} \\
\hline & $\ln (x+2300)$ & Back-transformed & $\ln (x+500)$ & Back-transformed & & \\
\hline \multicolumn{7}{|c|}{ 'Resistant' parents } \\
\hline Iraq 43 & 9.13 & 6918 & 8.14 & 2943 & $-0.78 * * *$ & $-0.44 * * *$ \\
\hline Morocco 426 & 9.30 & 8649 & 8.72 & 5649 & $-0.55^{* *}$ & $-0.45 * * *$ \\
\hline Persia 11 & 9.01 & 5885 & 9.08 & 8234 & -0.24 & -0.05 \\
\hline Persia 62 & 9.31 & 8717 & 10.70 & 43989 & -0.12 & 0.14 \\
\hline GS50a & 9.30 & 8631 & 8.45 & 4166 & -0.09 & 0.01 \\
\hline C-70-3 & 8.71 & 3775 & 9.08 & 8260 & 0.01 & 0.06 \\
\hline El Neilain & 10.32 & 27920 & - & - & 0.27 & - \\
\hline Persia 28 & 10.15 & 23413 & - & - & $0.33^{*}$ & - \\
\hline Iraq 48 & 11.10 & 64138 & 10.79 & 47888 & $0.58 * *$ & $0.74 * * *$ \\
\hline Persia 92 & 9.66 & 13431 & - & - & $0.60 * *$ & - \\
\hline \multicolumn{7}{|c|}{ Reference standards } \\
\hline Unplanted & 7.92 & 451 & 7.19 & 823 & - & - \\
\hline Canaryseed & 8.21 & 1385 & 7.14 & 765 & - & - \\
\hline QT9048 & 9.27 & 8317 & 8.66 & 5268 & - & - \\
\hline Yallaroi & 9.57 & 12047 & 9.22 & 9597 & - & - \\
\hline QT8343 & 9.67 & 13506 & 8.50 & 4405 & - & - \\
\hline Janz & 11.25 & 74440 & 11.19 & 71686 & - & - \\
\hline Gatcher & 11.77 & 127244 & 11.41 & 89990 & - & - \\
\hline Cunningham & 12.23 & 202462 & 11.77 & 128556 & - & - \\
\hline Batavia & 12.55 & 280528 & 12.56 & 285286 & - & - \\
\hline$F$ 1.s.d. $(P=0.05)$ & 0.65 & - & 0.95 & - & - & - \\
\hline $\mathrm{CV}(\%)$ & 5.8 & - & 8.7 & - & - & - \\
\hline
\end{tabular}

supplementary table 1$)$. In the $\mathrm{F}_{1}$ generation, only the mean of Iraq43/Iraq 48, (which had the greatest SCA for resistance) was significantly less $(P<0.001)$ than the mid-parent value, whereas 9 other hybrids were significantly greater $(P<0.001$ for Persia 92/Iraq 48, Persia 92/El Neilain, Persia 92/C-70-3; $P<0.01$ for Persia 11/Iraq 48, Persia 28/Morocco 426; and $P<0.05$ for Persia 62/C-70-3, Persia 28/C-70-3, Persia 92/GS50a, C-770-3/Iraq 48) than respective mid-parent values. Overall these results indicate very little heterosis for resistance to $P$. thornei among these 'resistant' parents. In the $\mathrm{F}_{2}$ generation, the means of 2 crosses, Persia 62/Morocco 426 and Persia 62/Persia 11 were significantly less than the mid-parent values. Of these 2, Persia 63/ Persia 11 had significant SCA effects for resistance in the $F_{2}$ diallel analysis.

All $20 \mathrm{~F}_{2}$ populations from the half-diallel of crosses between the 7 'resistant' parents showed continuous distributions of nematode numbers. Examples of two extremes of populations are given in Fig. 3. The $F_{2}$ population of the hybrid Iraq 43/ Morocco 426 (Fig. $3 a$ ) had a much lower mean number of nematodes than the hybrid Persia 62/Iraq 48 (Fig. 3b), although in both populations there were individuals with relatively lower and relatively higher nematode numbers.

Numbers of transgressive segregants for resistance and susceptibility (based on transformed data) in each of the crosses are given in Table 3. The highest number of transgressive segregants for resistance (Table 3) was produced by Persia 62/Iraq 48, the 2 least resistant parents. Persia 62 also produced transgressive segregants for resistance in other crosses with C-70-3, GS50a, Persia 11 and Morocco 426. Of the 2 parents with significant GCA effects for resistance, Morocco 426 produced moderately large numbers of transgressive segregants for resistance in several crosses (with Persia 62, GS50a and Iraq 48) whereas Iraq 43 did not. Most transgressive segregants for susceptibility were produced in the crosses Morocco 426/GS50a and Iraq 43/C-70-3. Transgressive segregation for resistance or susceptibility is measured against respective parental values within a cross whereas greatest genetic variation for resistance/susceptibility in these populations is among crosses. Transgressive segregants for resistance in one cross can be more susceptible than progeny in another cross that are not considered to be transgressive segregants for resistance.

Experiments 2 and 4 . Resistance to $\mathrm{P}$. thornei of $F_{1}$ hybrids and $F_{2}$ populations from crosses between 'resistant' wheat accessions and the susceptible Australian wheat CV. Janz

Number of $P$. thornei after growth of the wheat reference standards and parents ranged from 349340 nematodes $/ \mathrm{kg}$ soil for the susceptible Australian cv. Gatcher down to 28010 for the resistant parent Morocco 426 in Expt 2 for $F_{1}$, and from 48040 for Janz down to 4710 for Morocco 426 in Expt 4 for $F_{2}$ (full results available as Accessory Publication, supplementary table 2). The 

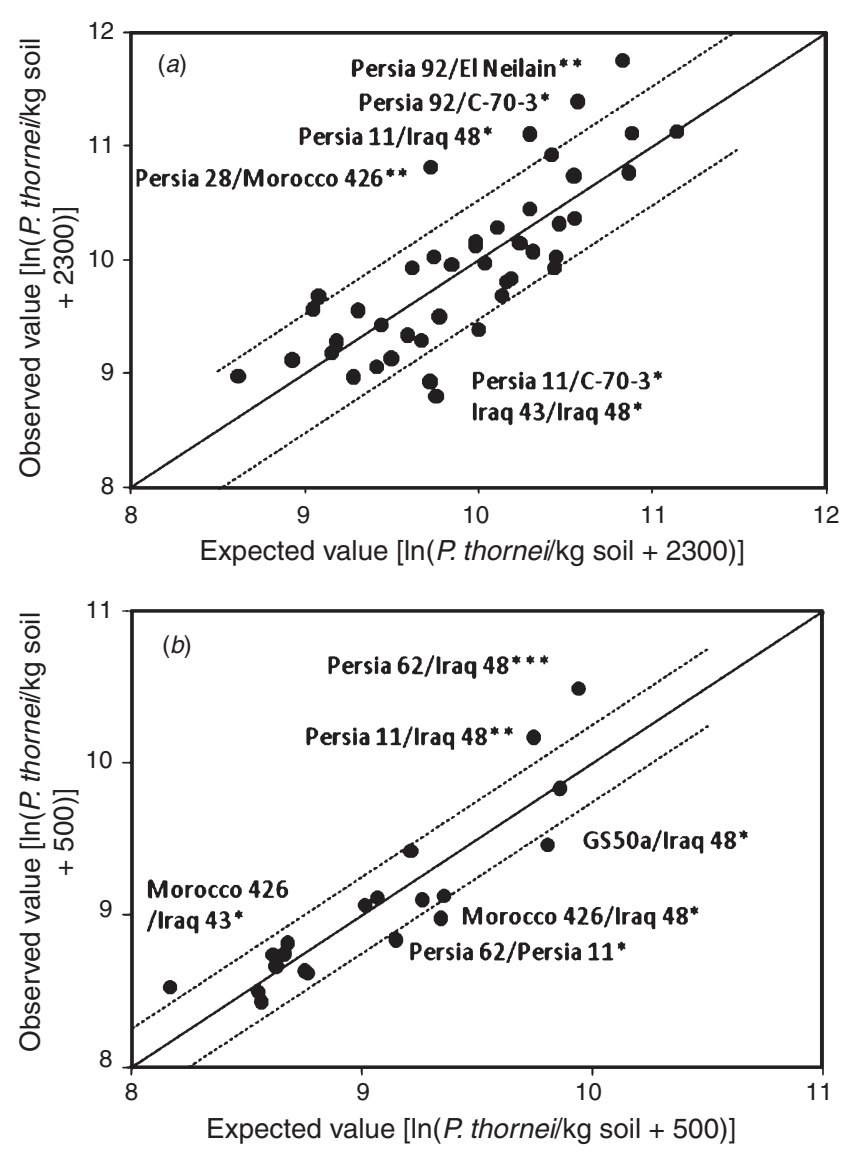

Fig. 1. Observed versus expected Pratylenchus thornei $[\ln (x+\mathrm{c})$ transformed means] for $(a)$ 'resistant' $\times$ 'resistant' $\mathrm{F}_{1}$ hybrids and $(b)$ their $\mathrm{F}_{2}$ populations from a half-diallel of crosses. Expected value is the grand mean plus the GCA of the respective 2 parents. The dotted lines show deviations of \pm 2 standard errors for observed cross means from the diagonal. The vertical distance of any point from the diagonal is the SCA together with the sampling error of the nematode numbers for the cross. SCA effect significantly different from zero at $* P<0.05,{ }^{*} * P<0.01$ and ${ }^{* * *} P<0.001$, respectively, from half-diallel ANOVA.

$\mathrm{F}_{1}$ mean was significantly lower than the mid-parent value for Iraq 48/Janz $(P<0.001)$, El Neilain/Janz $(P<0.05)$ and Iraq $43 / \mathrm{Janz}(P<0.05)$ and significantly higher for Persia $92 / \mathrm{Janz}$ $(P<0.01)$. All plants of the $\mathrm{F}_{1}$ hybrid Iraq $48 /$ Janz grew as 'grass clumps' with phenological development arrested at growth stage 11 (Zadoks et al. 1974). It is probable that this genetic condition also affected root growth resulting in abnormally low nematode reproduction in Iraq 48/Janz $F_{1}$. Parameters to the $\mathrm{F}_{2}$ populations are summarised in Table 4 . The $\mathrm{F}_{2}$ mean was significantly lower $(P<0.05)$ than the mid-parent value for Morocco 426/Janz and Persia 62/Janz. The mean back-transformed values ranged from 5730 and 7295 P. thornei/kg soil for Morocco 426/Janz and Iraq 43/Janz, respectively, up to $51354 / \mathrm{kg}$ soil for Persia 92/Janz. Morocco 426/Janz and Iraq 43/Janz also had lower median values than the mean indicating some skewing towards resistance.

Regression analyses were conducted to investigate whether GCA effects of the 'resistant' parents obtained from $F_{1}$ and $F_{2}$ diallel analyses were predictive of the mean number of $P$. thornei produced in crosses of these 'resistant' parents with the
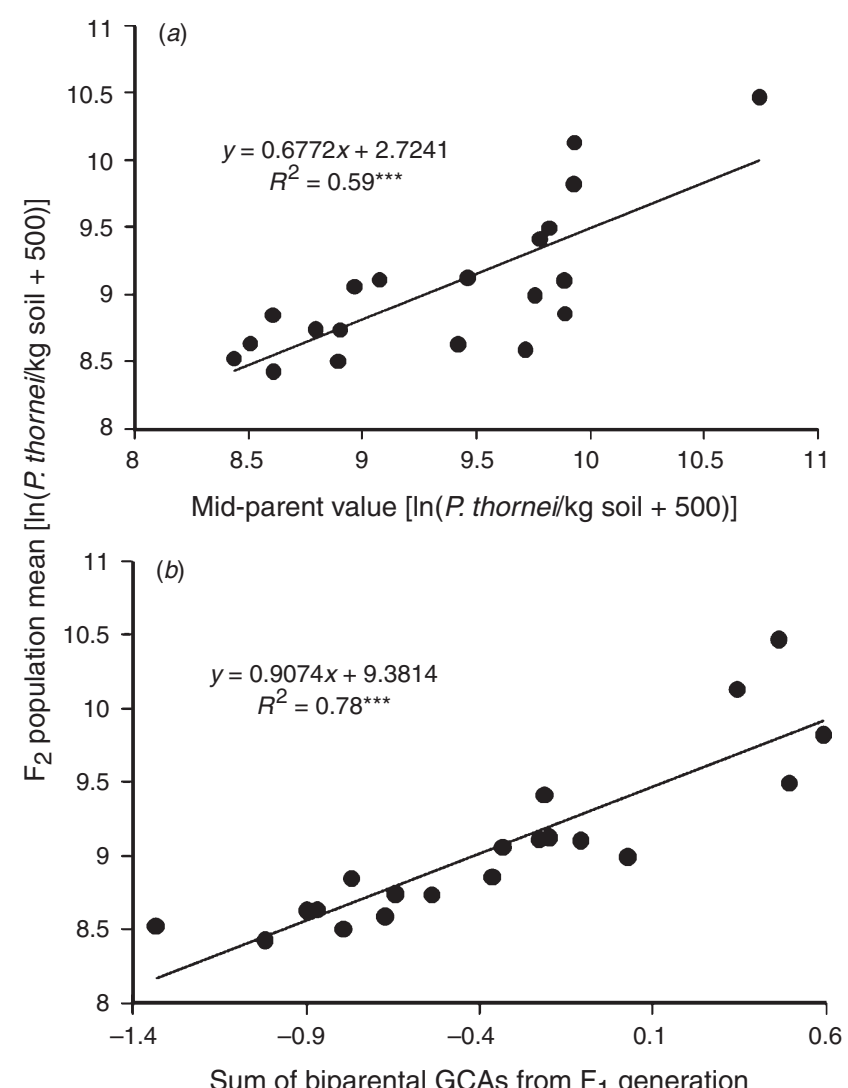

Fig. 2. Mean numbers of Pratylenchus thornei for $20 \mathrm{~F}_{2}$ populations (Expt 3) regressed against (a) mid-parent values (Expt 3) and (b) sum of biparental GCA effects based on the $\mathrm{F}_{1}$ generation (Expt 1).

susceptible wheat $\mathrm{cv}$. Janz at the $\mathrm{F}_{1}$ and $\mathrm{F}_{2}$ generations (Fig. 4). There were highly significant linear regression relationships (Fig. 4) between (i) $\mathrm{F}_{1}$ means of crosses of 'resistant' parents with Janz against GCA of the 'resistant' parent from $\mathrm{F}_{1}$ diallel analysis $\left(R^{2}=0.86\right.$, d.f. $\left.=7, P<0.001\right)$, (ii) $\mathrm{F}_{2}$ means of crosses of 'resistant' parents with Janz against GCA of the 'resistant' parent from $\mathrm{F}_{1}$ diallel analysis $\left(R^{2}=0.83\right.$, d.f. $=8, P<0.001$ ), and (iii) $\mathrm{F}_{2}$ means of crosses with Janz against GCA of the resistant parent from $\mathrm{F}_{2}$ diallel analysis $\left(R^{2}=0.90\right.$, d.f. $=5, P<0.001)$.

The $F_{2}$ populations of the 'resistant' parent $\times$ Janz crosses showed relatively continuous distribution patterns (see Accessory Publication, supplementary fig. 1). Frequency histograms of transformed nematode counts (Accessory Publication, supplementary fig. 2) showed relatively normal distributions with skewing towards resistance in the case of Morocco 426/Janz and Iraq 43/Janz, crosses of the 2 wheats with greatest GCA effects for resistance and Janz.

\section{Experiment 5. Resistance to $\mathrm{P}$. thornei of $\mathrm{DH}$ populations from crosses between 'resistant' parents and Janz}

Frequency distribution histograms of the DH populations (see Accessory Publication, supplementary fig. 3) showed relatively continuous distributions with skewing towards resistance in the case of Morocco 426/Janz and Iraq 43/Janz and a somewhat 


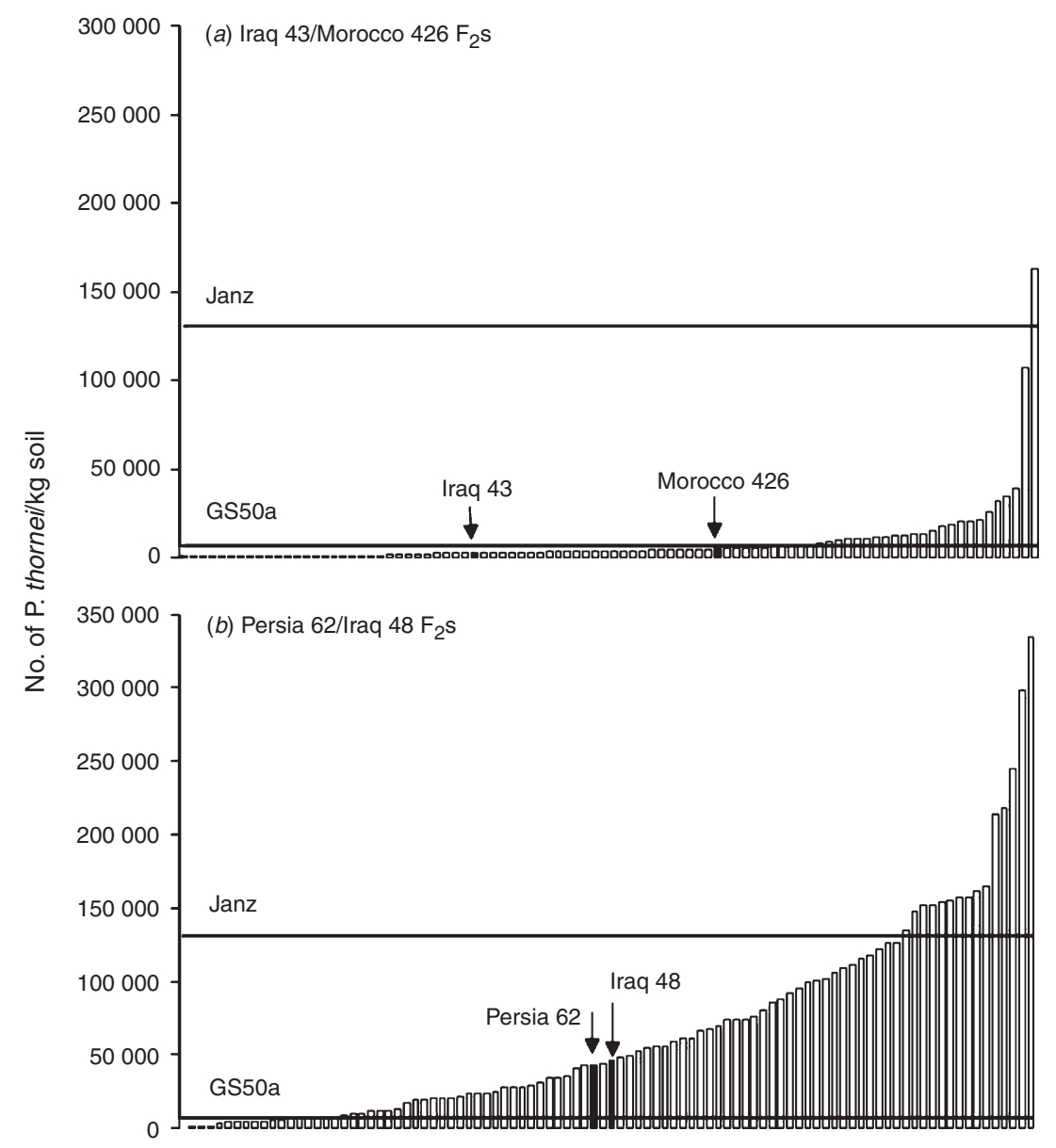

Fig. 3. Number of Pratylenchus thornei $/ \mathrm{kg}$ soil after growth of $\mathrm{F}_{2}$ populations from crosses of (a) Iraq $43 \times$ Morocco 426 (parents with the largest GCA effects for resistance in $\mathrm{F}_{1}$ hybrids) and (b) Persia $62 \times$ Iraq 48 (parents with the largest GCA effects for susceptibility in $\mathrm{F}_{1}$ hybrids), compared with the susceptible cv. Janz and the partially resistant GS50a shown as horizontal lines.

Table 3. Number of transgressive segregants for resistance (above the diagonal) and for susceptibility (below the diagonal) to Pratylenchus thornei in $\mathrm{F}_{2}$ populations from crosses of 'resistant' $\times$ 'resistant' wheat accessions (Expt 3) Transgressive segregants are individuals with $95 \%$ probability of falling below or exceeding the means of the more resistant or more susceptible parent based on $\ln (P$. thornei $\mathrm{kg}$ soil +500$)$ transformations

\begin{tabular}{lcccccrr}
\hline Parent & Iraq 43 & Morocco 426 & Persia 11 & Persia 62 & GS50a & C-70-3 & Iraq 48 \\
\hline Iraq 43 & & 0 & 0 & 0 & 0 & 0 & 0 \\
Morocco 426 & 2 & & 3 & 7 & 11 & 2 & 10 \\
Persia 11 & 0 & 0 & & 6 & 2 & 7 & 1 \\
Persia 62 & 0 & 0 & 0 & & 5 & 7 & 18 \\
GS50a & 0 & 8 & 3 & 1 & & - & 3 \\
C-70-3 & 7 & 0 & 1 & 0 & - & & 1 \\
Iraq 48 & 0 & 0 & 1 & 2 & 0 & 0 & \\
\hline
\end{tabular}

bimodal distribution in the case of El Neilain/Janz. The mean number of $P$. thornei for the DH populations was lower for Morocco 426/Janz, Iraq 43/Janz and GS50a/Janz than for Persia 11/Janz and El Neilain/Janz (Table 5). There were no significant differences between means of the $\mathrm{DH}$ populations and mid-parent values (Table 5). The heritability (narrow-sense) on a line mean basis of $P$. thornei resistance ranged from 0.82 for the GS50a/Janz population to $0.91-0.92$ for the 4 'resistant' parent/Janz populations (Table 5). Estimates of the minimum number of genes controlling resistance to $P$. thornei ranged from 1.7 in GS50a/Janz to 5.5 in Morocco 426/Janz (Table 5). 

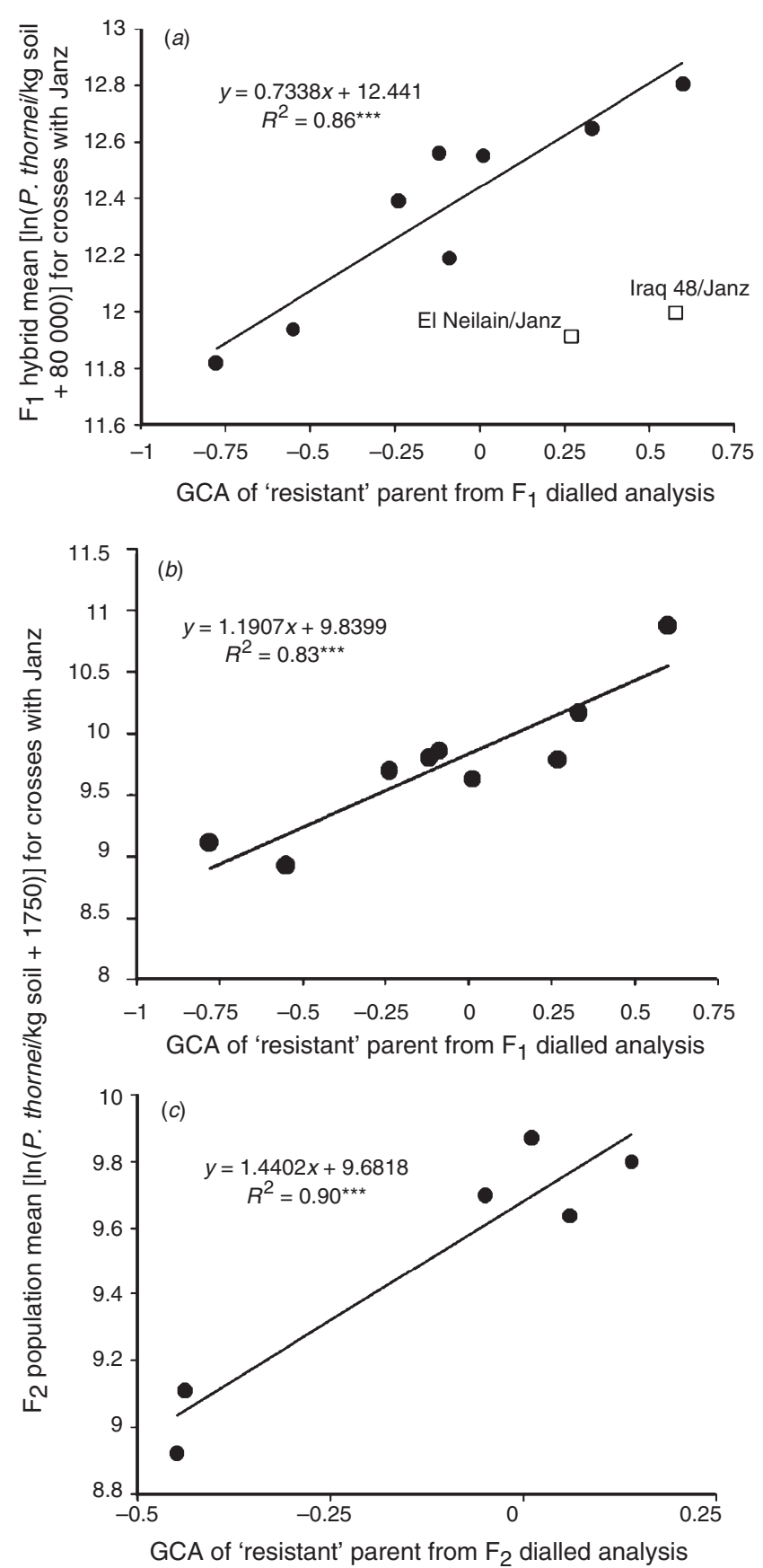

Fig. 4. Mean number of Pratylenchus thornei $/ \mathrm{kg}$ soil $[\ln (x+\mathrm{c})$ transformations] after 16 weeks' growth in the glasshouse of crosses of 'resistant' parents $\times \operatorname{Janz}(a) \quad \mathrm{F}_{1}$ hybrid means (Expt 2) and (b) $\mathrm{F}_{2}$ population means (Expt 4) regressed against GCA values from $F_{1}$ halfdiallel analysis (Expt 1) and (c) $\mathrm{F}_{2}$ population means (Expt 4) regressed against GCA values from $F_{2}$ half-diallel analysis (Expt 3 ). Two $F_{1}$ hybrids (Iraq 48/Janz, which grew as 'grass clumps', and El Neilain/Janz) were apparent outliers and were not included in the regression analysis in Fig. $4 a{ }^{* * *}=$ coefficient of determination statistically significant at $P<0.001$.

The mean number of $P$. thornei for the $\mathrm{DH}$ populations was significantly related to the GCA value of the resistant parents determined by half-diallel analysis of $F_{1}$ crosses in Expt 1 (Fig. 5).

\section{Experiment 6. Resistance to P. neglectus of WANA} wheats resistant to $\mathrm{P}$. thornei

The $P$. thornei-resistant WANA wheats and GS50a produced high populations of $P$. neglectus comparable to Australian cultivars used as reference standards (Table 6). Persia 28 produced the lowest number of $P$. neglectus among this group of $P$. thornei-resistant WANA wheat accessions, but this was significantly higher than the resistance standards for $P$. neglectus, namely Persia 20 and Virest.

\section{Discussion}

The results of this investigation show that GCA is much more important than SCA in the inheritance of resistance to $P$. thornei among the best sources of resistance that had previously been identified in 2 collections of wheat from WANA countries (Thompson et al. 2009). Christie and Shattuck (1992) stated that a relatively large GCA/SCA variance ratio indicates the importance of additive gene effects, and a low ratio implies the presence of dominant and/or epistatic gene effects (Griffing 1956; Bhullar et al. 1979). Where SCA is small relative to GCA, performance of single-cross progeny can be predicted on the basis of the GCA of the parents. For inbred parents, the closer Baker's ratio of components of variance is to unity, the greater the predictability based on GCA (Baker 1978). Thus, the GCA effects for $P$. thornei resistance established at the $F_{1}$ generation of the half-diallel of 'resistant' parents were quite predictive of the average performance of their crosses at the $F_{2}$ generation, and of crosses of these 'resistant' parents with Janz at the $F_{1}, F_{2}$ and $F_{\infty}(D H)$ generations. Comparison of mean values of hybrids with their mid-parent values provided little evidence that heterosis was important in reducing numbers of $P$. thornei and consequently in an inbreeding crop like wheat the resistance identified in early generations will be retained in successive generations. The presence of transgressive segregants for resistance in the $F_{2}$ progeny indicated that different resistance genes from the 2 parents are segregating in many of the crosses and contributing to the level of resistance obtained. In particular, Morocco 426 resulted in transgressive segregants for resistance in most crosses whereas Iraq 48 did not. There were 2 transgressive segregants for susceptibility in the cross Morocco 426/Iraq 43 indicating that some of the resistance genes in the 2 accession with the highest GCA values for resistance are different. Thus, it is likely that in several instances by using more than one source of resistance in polycrosses, progeny that are more resistant than the parents might be obtained. The lack of transgressive segregants for susceptibility in many of the crosses indicates that their parents are likely to have at least 1 resistance gene in common.

Analysis of $\mathrm{DH}$ populations indicated that a minimum of from 2 to 6 effective resistance genes were involved in different crosses of 5 'resistant' parents with Janz, which is consistent with other research showing the polygenic nature of resistance to P. thornei in synthetic hexaploid wheat (Zwart et al. 2004, 2005; Thompson 2008). The parents Morocco 426 and Iraq 43 that had the largest GCA effects for resistance in both $F_{1}$ and $F_{2}$ 
Table 4. Parameters of $F_{2}$ populations from 9 crosses of 'resistant' parents $\times$ Janz for $\ln ($ Pratylenchus thornei $/ \mathrm{kg}$ soil +1750$)$

\begin{tabular}{|c|c|c|c|c|c|c|c|c|c|}
\hline \multirow{2}{*}{$\begin{array}{l}\text { Parameter } \\
\text { of } F_{2} \text { population }\end{array}$} & \multicolumn{9}{|c|}{ 'Resistant' parent in cross with Janz } \\
\hline & Morocco 426 & Iraq 43 & C-70-3 & Persia 11 & Persia 62 & GS50a & El Neilain & Persia 28 & Persia 92 \\
\hline Number & 103 & 107 & 108 & 108 & 107 & 107 & 107 & 108 & 109 \\
\hline Minimum & 7.47 & 7.56 & 7.66 & 7.70 & 7.59 & 7.64 & 7.84 & 7.47 & 8.60 \\
\hline Maximum & 11.92 & 12.00 & 12.05 & 11.97 & 12.73 & 12.14 & 12.43 & 12.45 & 13.5 \\
\hline Median & 8.73 & 8.80 & 9.65 & 9.65 & 9.82 & 9.98 & 9.76 & 10.40 & 10.88 \\
\hline Mean & $8.92 *$ & 9.11 & 9.64 & 9.70 & $9.80 *$ & 9.87 & 9.80 & 10.17 & 10.88 \\
\hline Mean $(B T)^{A}$ & 5730 & 7295 & 13617 & 14568 & 16284 & 17591 & 16284 & 24358 & 51354 \\
\hline $\mathrm{MPV}^{\mathrm{B}}$ & 9.79 & 9.81 & 9.91 & 10.16 & 10.71 & 9.83 & 10.16 & 10.39 & 10.39 \\
\hline Variance & 0.90 & 1.14 & 1.31 & 0.82 & 1.04 & 0.98 & 1.24 & 1.41 & 1.02 \\
\hline
\end{tabular}

${ }^{\mathrm{A}} \mathrm{BT}=$ back-transformed mean from $\ln (P$. thornei $/ \mathrm{kg}$ soil +1750$)$.

${ }^{\mathrm{B}} \mathrm{MPV}=$ mid-parent value; * = mean significantly different from MPV at $P<0.05$.

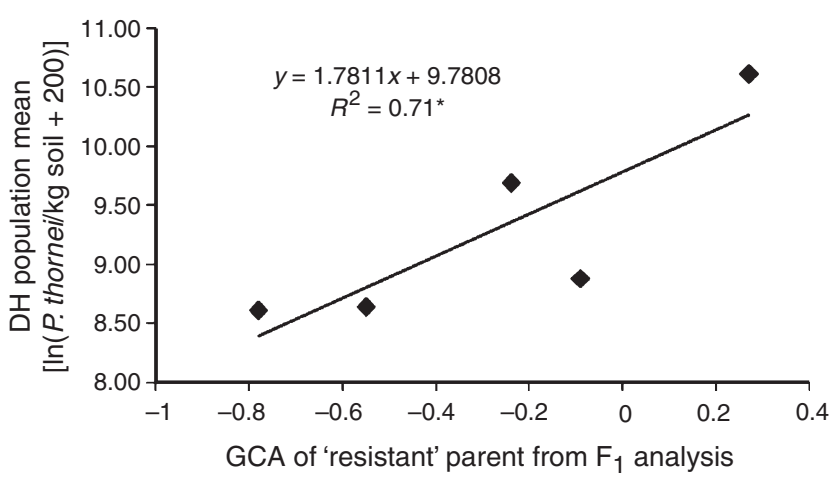

Fig. 5. Number of Pratylenchus thornei $/ \mathrm{kg}$ soil after 16 weeks' growth of doubled-haploid populations (126 individuals) from crosses between 5 'resistant' parents and the susceptible Australian cv. Janz (Expt 5), regressed against GCA values of the 'resistant parents' determined from half-diallel analysis of $\mathrm{F}_{1}$ hybrids (Expt 1 ). ${ }^{*}=$ coefficient of determination statistically significant at $P<0.05$.

diallel analyses consistently produced the most resistant progeny, both in crosses with other 'resistant' parents and in crosses with Janz. Morocco 426 and Iraq 43 crosses with Janz had respectively a minimum of 6 and 4 genes segregating for resistance. Morocco 426 and Iraq 43 would be the best parents to use in wheat breeding programs and some of their resistant $\mathrm{DH}$ derivatives identified in this study offer a fixed source of resistance in a background that is already half of the widely adapted Australian cv. Janz. However, none of these sources of resistance to $P$. thornei are resistant to $P$. neglectus and additional crossing with a source of resistance to $P$. neglectus would be necessary if dual resistance was required. In this regard synthetic hexaploid wheat accessions with dual resistance (Thompson 2008) offer initial advantages in a crossing program but may result in more linkage drag than landraces.

The polygenic, quantitative nature of resistance to $P$. thornei in wheat and lack of races of the nematode species, contrasts with resistance to $\mathrm{CCN}$ where single major genes for resistance have been used in wheat breeding programs and pathotypes of the nematode species exist (Smiley and Nicol 2009). Sources of resistance to $P$. thornei such as Morocco 426 and Iraq 43 already have resistance genes combined (pyramided) and the task will be to retain these when crossing with susceptible Australian cultivars and selecting progeny for resistance. This study has found relatively high heritabilities for $P$. thornei resistance with the genetic material and the screening methods used here. Because of the additive mode of inheritance, heterozygous plants show an intermediate level of resistance between homozygous resistant and homozygous susceptible plants. Therefore, $\mathrm{BC}_{1}$ plants can be selected by the quantitative test for nematode resistance as used

Table 5. Parameters of doubled-haploid (DH) populations from 5 crosses of 'resistant' parents $\times$ Janz for $\ln \left(\right.$ Pratylenchus thornei $/ \mathbf{k g}$ soil $\left.+\mathrm{c}^{\mathrm{A}}\right)$

\begin{tabular}{|c|c|c|c|c|c|}
\hline \multirow[t]{2}{*}{ Parameter } & \multicolumn{5}{|c|}{ Resistant parent of DH with Janz } \\
\hline & Morocco 426 & Iraq 43 & GS50a & Persia 11 & El Neilain \\
\hline Mean of DH & $8.64(5431)$ & $8.61(5292)$ & $8.88(6708)$ & $9.71(16216)$ & $10.62(40364)$ \\
\hline Mid-parent value ${ }^{\mathrm{B}}$ & 8.56 & 8.72 & 8.98 & 9.89 & 10.35 \\
\hline 1.s.d. $(P=0.05)$ & 1.01 & 0.94 & 1.04 & 0.77 & 1.13 \\
\hline Minimum & 6.70 & 7.09 & 7.17 & 7.98 & 8.72 \\
\hline Maximum & 12.02 & 11.37 & 10.66 & 12.07 & 12.35 \\
\hline Range (Ra) & 5.32 & 4.28 & 3.48 & 4.09 & 3.63 \\
\hline Heritability $^{\mathrm{D}}\left(h^{2}\right)$ & 0.92 & 0.91 & 0.82 & 0.91 & 0.91 \\
\hline Minimum no. of effective genes ${ }^{\mathrm{E}}(n)$ & 5.5 & 3.4 & 1.7 & 3.2 & 2.4 \\
\hline
\end{tabular}

\footnotetext{
${ }^{\mathrm{A}} \mathrm{c}=200$ for first 3 crosses and 500 for last 2; back-transformed means ( $P$. thornei/kg soil) in parentheses.

${ }^{\mathrm{B}}$ No significant difference between mid-parent value and mean of $\mathrm{DH}$ populations.

${ }^{\mathrm{C}}$ Genetic variance $\left(\sigma_{\mathrm{g}}^{2}\right)=\left(\sigma_{\mathrm{dhl}}^{2}-\sigma_{\mathrm{e})}^{2} / r\right.$ where $\sigma_{\mathrm{dhl}}^{2}=$ phenotypic variance of the DH lines, $\sigma_{\mathrm{e}}^{2}=$ error variance and $r=$ no. of replicates.

DHeritability $\left(h^{2}\right)=\sigma_{\mathrm{g}}^{2} /\left(\sigma_{\mathrm{g}}^{2}-\sigma_{\mathrm{e}}^{2} / r\right)$ on a line mean basis for fixed lines in an experimental design (Fehr 1987).

${ }^{\mathrm{E}}$ Minimum number of effective genes $(n)=\mathrm{Ra}^{*} h^{2} / 4 * \sigma_{\mathrm{g}}^{2}$ (Herrera-Foessel et al. 2008; S. A. Herrera-Foessel, pers. comm. 2010).
} 
Table 6. Number of Pratylenchus neglectus/kg soil after 16 weeks' growth in the glasshouse of $P$. thornei-'resistant' WANA wheats compared with reference standards and other Australian wheat cultivars

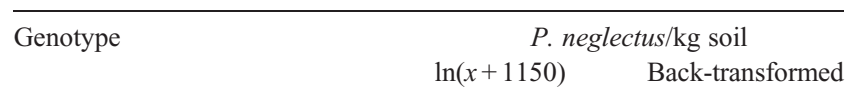

\begin{tabular}{lcc}
\hline & WANA wheats and GS50a \\
Persia 28 & 11.58 & 106093 \\
Persia 92 & 12.12 & 182741 \\
C-70-3 & 12.72 & 333372 \\
Iraq 43 & 12.75 & 343562 \\
Persia 11 & 12.80 & 362551 \\
Persia 62 & 12.95 & 417984 \\
Iraq 48 & 13.24 & 561199 \\
E1 Neilain & 13.32 & 608275 \\
GS50a & 13.40 & 662047 \\
Morocco 426 & 13.40 & 659396
\end{tabular}

\begin{tabular}{lcr}
\multicolumn{3}{c}{ Reference standards and other Australian cultivars } \\
Unplanted & 8.25 & 2684 \\
Persia 20 (W) & 9.95 & 19883 \\
Virest (W) & 10.42 & 32463 \\
Abacus (T) & 10.85 & 50617 \\
Spear (SW) & 11.91 & 147509 \\
Suneca (NW) & 11.95 & 154386 \\
Yallaroi (ND) & 11.96 & 155020 \\
Canaryseed & 11.97 & 156440 \\
Gatcher (NW) & 12.49 & 263800 \\
Krichauff (SW) & 12.59 & 292309 \\
Cunningham (NW) & 12.66 & 313765 \\
Excalibur (SW) & 12.67 & 316955 \\
QT9048 (NW) & 12.80 & 361979 \\
Janz (NW) & 12.93 & 410117 \\
Machete (SW) & 12.94 & 417037 \\
Worrakatta (SW) & 12.96 & 422897 \\
Batavia (NW) & 13.00 & 441720 \\
QT8343 (NW) & 13.48 & 714977 \\
$F$ 1.s.d. (P $=0.05)$ & 0.84 & - \\
CV (\%) & 7.3 & -
\end{tabular}

$\mathrm{W}=$ wheat, $\mathrm{D}=$ durum, $\mathrm{T}=$ triticale, $\mathrm{NW}=$ Australian wheat cultivar from northern region, $\mathrm{SW}=$ Australian wheat cultivar from southern region.

here and this facilitates backcrossing resistance into adapted parents (J. P. Thompson and J. G. Sheedy, unpubl. data). Molecular markers may be useful in this regard with further development and validation. Significant quantitative trait loci (QTL) for resistance to $P$. thornei coming from Moroccco 426 were found on chromosomes $2 \mathrm{~B}$ and $3 \mathrm{~B}$ in the cross Morococo $426 /$ Janz, and coming from Iraq 43 on chromosomes 2B, 3B and $6 \mathrm{D}$ in the cross Iraq $43 / \mathrm{Janz}$ by composite interval mapping (Schmidt et al. 2005). Composite interval mapping also revealed a susceptibility locus coming from Janz on chromosome 1B in the cross Iraq 43/Janz (Schmidt et al. 2005). While QTL for resistance to $P$. thornei had previously been reported on group 6 chromosomes (6B and 6D) in GS50a (Vicars et al. 1999) and on chromosomes 2BS, 6DS and 6DL in synthetic hexaploid wheat accessions (Zwart et al. 2005, 2006, 2009), 3B was a novel locus for resistance found in Morocco 426 and Iraq 43.

While several QTL for resistance to $P$. thornei have been discovered, in total they explain only a fraction of the variation for resistance in the populations studied and fewer QTL have been detected than the number of effective genes for resistance calculated in this study (Morocco 426/Janz, 2 QTL, minimum 6 genes), (Iraq 43/Janz, 4 QTL, minimum 4 genes), (GS50a/Janz, 2 QTL, minimum 2 genes). To obtain a reliable system for marker-assisted selection for resistance to $P$. thornei, further research is required to find more loci, develop more closely associated markers and validate them in breeding populations.

Hill (2010) recently indicated that in selection for quantitative genetic variation, methods based on summary statistics and predictions will continue to be more useful than selection at the individual gene level for some time yet. Similarly, Keane (2010) advocated selection for 'resistance' rather than for 'resistance genes' giving the example of successful selection for resistance to vascular-streak dieback (caused by the basidiomycete Oncobasidium theobromae) among a genetically diverse population of cocoa clones in New Guinea. Results from the International Maize and Wheat Improvement Centre, Mexico (CIMMYT) in using polygenically inherited resistance to leaf rust (Singh et al. 2004) provide an analogous model for utilising polygenic resistance to $P$. thornei. Singh et al. (2004) reported that deploying wheat cultivars with durable resistance to leaf rust based on additively inherited minor genes is necessary for long-term success. Their studies showed that at least 10-12 slow-rusting genes were involved in adult plant resistance of CIMMYT wheat germplasm and the combination of $2-3$ or $4-5$ of these minor genes in a single cultivar provided moderate and high levels of resistance, respectively. They also indicated their success has depended on a relevant phenotypic screen for resistance and the recombination of enough of these genes in single parental lines.

This study confirms the polygenic nature of resistance to $P$. thornei and shows the potential value of these WANA sources of resistance in contributing a diversity of resistance genes to Australian bread wheat cultivars. Such wheat cultivars with enhanced resistance would also be of value in other countries where $P$. thornei causes yield loss. The accessions identified with the best GCA effects for resistance can be used effectively to breed resistance into adapted Australian cultivars using current phenotypic screening methods.

\section{Acknowledgements}

This work was financially supported by the Grains Research and Development Corporation. We thank Mr L. Mason for performing the crosses for the half-diallel, Dr N. Howes for production of the doubledhaploids, and Dr D. Butler and Ms K. L. Bell for assistance with statistical analyses. We also thank Drs P. S. Brennan, R. S. Zwart, I. C. DeLacy, R. P. Singh, and S. A. Herrera-Foessel for helpful discussions at various stages of this investigation.

\section{References}

Baker RJ (1978) Issues in diallel analysis. Crop Science 18, 533-536. doi:10.2135/cropsci1978.0011183X001800040001x

Berry DA (1987) Logarithmic transformations in ANOVA. Biometrics 43, 439-456. doi:10.2307/2531826

Bhullar GS, Gill KS, Khehra AS (1979) Combining ability analysis over $\mathrm{F}_{1}-\mathrm{F}_{2}$ generations in diallel crosses of bread wheat. Theoretical and Applied Genetics 55, 77-80. doi:10.1007/BF00285194 
Burow MD, Coors JG (1994) DIALLEL: a microcomputer program for the simulation and analysis of diallel crosses. Agronomy Journal 86, 154-158. doi:10.2134/agronj1994.00021962008600010028x

Christie BR, Shattuck VI (1992) The diallel cross: design, analysis, and use for plant breeders. Plant Breeding Reviews 9, 9-36.

Cockerham CC (1983) Covariances of relatives from self-fertilization. Crop Science 23, 1177-1180. doi:10.2135/cropsci1983.0011183X0023 $00060035 \mathrm{x}$

Das RK, Vanstone VA, Russ MH, Rathjen AJ (2004) Development of bread and durum wheats for resistance to Pratylenchus neglectus. In 'Third Australasian Soilborne Diseases Symposium'. Barossa Valley. (Eds B Hall, K Ophel Keller) pp. 207-208. (The South Australian Research and Development Institute, Department of Primary Industries and Resources: Adelaide, SA)

DPIF (2009) 'Wheat varieties for Queensland 2009.' (The State of Queensland, Department of Primary Industries and Fisheries: Brisbane) Available at: www.dpi.qld.gov.au/26_5121.htm

Eckhardt RC (1952) Predicting yields of missing single crosses of corn. Agronomy Journal 44, 215-216. doi:10.2134/agronj1952.0002196200 $4400040012 x$

Falconer DS, Mackay TFC (1996) 'Introduction to quantitative genetics.' (Longman: Essex, UK)

Farsi M, Vanstone VA, Fisher JM, Rathjen AJ (1995) Genetic variation in resistance to Pratylenchus neglectus in wheat and triticales. Australian Journal of Experimental Agriculture 35, 597-602. doi:10.1071/ EA9950597

Fehr WA (1987) Heritability, Ch. 7. In 'Principles of cultivar development'. pp. 95-105. (Macmillan Publishing Company: New York)

Gilmour RA, Gogel BJ, Cullis BR, Welham S, Thompson R (2002) 'ASReml user guide release 1.0.' (VSN International: Hemel Hempstead, UK)

Griffing B (1956) Concept of general and specific combining ability in relation to diallel crossing systems. Australian Journal of Biological Sciences 9, 463-493.

Herrera-Foessel SA, Singh RP, Huerta-Espino J, Crossa J, Djurle A, Yuen J (2008) Genetic analysis of slow-rusting resistance to leaf rust in durum wheat. Crop Science 48, 2132-2140. doi:10.2135/cropsci2007. 11.0606

Hill WG (2010) Understanding and using quantitative genetic variation. Philosophical Transactions of the Royal Society B 365, 73-85. doi:10.1098/rstb.2009.0203

Keane PJ (2010) Lessons from the tropics - plant diversity, unusual and changeable pathology, horizontal resistance, and the plight of farmers. Australasian Plant Pathology 39, 192-210. doi:10.1071/ AP09081

Miller TE, Ambrose MJ, Reader SM (2001) The Watkins Collection. In 'Wheat taxonomy: The legacy of John Percival'. (Eds PDS Caligari, PE Brandham) pp. 113-120. (Academic Press: London)

Murray GM, Brennan JP (2009) Estimating disease losses to the Australian wheat industry. Australasian Plant Pathology 38, 558-570. doi:10.1071/ AP09053

Navabi A, Singh RP, Tewari JP, Briggs KG (2004) Inheritance of high levels of adult-plant resistance to stripe rust in five spring wheat genotypes. Crop Science 44, 1156-1162. doi:10.2135/cropsci2004.1156

Nicol J, Rivoal R, Taylor S, Zaharieva M (2003) Global importance of cyst (Heterodera spp.) and lesion nematodes (Pratylenchus spp.) on cereals: distribution, yield loss, use of host resistance and integration of molecular tools. Nematology Monographs and Perspectives 2, 1-19.

Nicol JM (1996) The distribution, pathogenicity, and population dynamics of Pratylenchus thornei on wheat in South Austalia. PhD Thesis, University of Adelaide.

Payne RW, Harding SA, Murray DA, Soutar DM, Baird DB, Welham SJ, Kane AF, Gilmour AR, Thompson R, Webster R, Tunnicliffe Wilson G (2008) 'Genstat for Windows.' 11th edn. (VSN International: Hemel Hempstead, UK)
Proctor JR, Marks CF (1974) The determination of normalising transformations for nematode count data from soil samples and of efficient sampling schemes. Nematologica 20, 395-406. doi:10.1163/ $187529274 X 00023$

Roberts PA (2002) Concepts and consequences of resistance. In 'Plant resistance to parasitic nematodes'. (Eds JL Starr, R Cook, J Bridge) pp. 23-41. (CABI Publishing: Wallingford, UK)

Schmidt AL, McIntyre CL, Thompson JP, Seymour NP, Liu CJ (2005) Quantitative trait loci for root lesion nematode (Pratylenchus thornei) resistance in Middle-Eastern landraces and their potential for introgression into Australian bread wheat. Australian Journal of Agricultural Research 56, 1059-1068. doi:10.1071/AR05016

Singh RP, Ma H, Rajaram S (1995) Genetic analysis of resistance to scab in spring wheat cultivar Frontana. Plant Disease 79, 238-240. doi:10.1094/ PD-79-0238

Singh RP, William HM, Huerta-Espino J, Rosewarne G (2004) Wheat rust in Asia: meeting the challenges with old and new technologies. In 'New directions for a diverse planet. Proceedings of the Fourth International Crop Science Congress'. 26 Sept.-1 Oct. 2004, Brisbane, Qld. (CDROM) (International Crop Science Society: Brisbane) Available at: www. cropscience.org.au

Smiley RW, Nicol JM (2009) Nematodes which challenge global wheat production. In 'Wheat science and trade'. (Ed. BF Carver) pp. 171-187. (Wiley Blackwell: Ames, IA)

Sprague GF, Tatum LA (1942) General versus specific combining ability in single crosses of corn. Journal of American Society of Agronomy 34, 923-932.

Thomas J, Chen Q, Howes N (1997) Chromosome doubling of haploids of common wheat with caffeine. Genome 40, 552-558. doi:10.1139/g97072

Thompson CH, Beckmann GG (1959) 'Soils and land use in the Toowoomba area, Darling Downs, Queensland.' Soils and Land Use Series No. 28. (Division of Soils, CSIRO: Melbourne)

Thompson JP (2008) Resistance to root-lesion nematodes (Pratylenchus thornei and $P$. neglectus) in synthetic hexaploid wheats and their durum and Aegilops tauschii parents. Australian Journal of Agricultural Research 59, 432-446. doi:10.1071/AR07222

Thompson JP, Brennan PS, Clewett TG, Sheedy JG, Seymour NP (1999) Progress in breeding for tolerance and resistance to root-lesion nematode (Pratylenchus thornei). Australasian Plant Pathology 28, 45-52. doi:10.1071/AP99006

Thompson JP, Clewett TG, Sheedy JG, Reen RA, O'Reilly MM (2010) Occurrence of root-lesion nematodes (Pratylenchus thornei and P. neglectus) and stunt nematode (Merlinius brevidens) in the northern grain region of Australia. Australasian Plant Pathology 39, 254-264. doi:10.1071/AP09094

Thompson JP, Haak MI (1997) Resistance to root-lesion nematode (Pratylenchus thornei) in Aegilops tauschii Coss., the D-genome donor to wheat. Australian Journal of Agricultural Research 48, 553-559. doi:10.1071/A96167

Thompson JP, Sheedy JG, Clewett TG (2000) 'Root-lesion nematodes. Northern Region Wheat Variety Trials 1995.' (Department of Primary Industries: Brisbane)

Thompson JP, O'Reilly MM, Clewett TG (2009) Resistance to the root-lesion nematode Pratylenchus thornei in wheat landraces and cultivars from the West Asia and North Africa (WANA) region. Crop \& Pasture Science 60, 1209-1217. doi:10.1071/CP09159

Thompson JP, Owen KJ, Stirling GR, Bell MJ (2008) Root-lesion nematodes (Pratylenchus thornei and P. neglectus): a review of recent progress in managing a significant pest of grain crops in northern Australia. Australasian Plant Pathology 37, 235-242. doi:10.1071/ AP08021

Trudgill DL (1991) Resistance to and tolerance of parasitic nematodes in plants. Annual Review of Phytopathology 29, 167-192. doi:10.1146/ annurev.py.29.090191.001123 
Vanstone VA, Hollaway GJ, Stirling GR (2008) Managing nematode pests in the southern and western regions of the Australian cereal industry: continuing progress in a challenging environment. Australasian Plant Pathology 37, 220-224. doi:10.1071/AP08020

Vanstone VA, Rathjen AJ, Ware AH, Wheeler RD (1998) Relationship between root lesion nematodes (Pratylenchus neglectus and P. thornei) and performance of wheat varieties. Australian Journal of Experimental Agriculture 38, 181-188. doi:10.1071/EA97109

Vicars L, Spindler L, Haak I, Wildermuth G, Thompson J, Banks P, Appels R, Lagudah E (1999) Genetic markers for resistance to crown rot and rootlesion nematodes. In 'Proceedings of the 9th Assembly of the Wheat Breeding Society of Australia'. pp. 118-120. (Wheat Breeding Society of Australia: Toowoomba, Qld)

Webb AA, Grundy MJ, Powell B, Littleboy M (1997) The Australian subtropical cereal belt: soils, climate and agriculture. In 'Sustainable crop production in the subtropics - an Australian perspective'. (Eds AL Clarke, PB Wylie) pp. 8-23. (Queensland Department of Primary Industries: Toowoomba, Qld)

Whitehead AG, Hemming JR (1965) A comparison of some quantitative methods of extracting small vermiform nematodes from soil. Annals of Applied Biology 55, 25-38. doi:10.1111/j.1744-7348.1965.tb07864.x

Wright S (1968) The genetics of quantitative variability. Ch 15. In 'Evolution and genetics of populations. A treatise in three volumes. Vol. I: Genetics and biometric foundations'. pp. 374-420. (The University of Chicago Press: Chicago and London)
Zadoks JC, Chang TT, Konzak CF (1974) A decimal code for the growth stages of cereals. Weed Research 14, 415-421. doi:10.1111/j.13653180.1974.tb01084.x

Zwart RS, Thompson JP, Godwin ID (2004) Genetic analysis of resistance to root-lesion nematode (Pratylenchus thornei Sher and Allen) in wheat. Plant Breeding 123, 209-212. doi:10.1111/j.1439-0523.2004.00986.x

Zwart RS, Thompson JP, Godwin ID (2005) Identification of quantitative trait loci for resistance to two species of root-lesion nematode (Pratylenchus thornei and P. neglectus) in wheat. Australian Journal of Agricultural Research 56, 345-352. doi:10.1071/AR04223

Zwart RS, Thompson JP, Milgate AW, Bansal UK, Williamson PM, Raman H, Bariana HS (2009) QTL mapping of multiple foliar disease and rootlesion nematode resistances in wheat. Molecular Breeding 106, $107-124$.

Zwart RS, Thompson JP, Sheedy JG, Nelson CJ (2006) Mapping quantitative trait loci for resistance to Pratylenchus thornei from synthetic hexaploid wheat in the International Triticeae Mapping Initiative (ITMI) population. Australian Journal of Agricultural Research 57, 525-530. doi:10.1071/ AR05177

Manuscript received 17 September 2010, accepted 15 December 2010 